\title{
Tecnologia de geolocalização: Grindr e Scruff redes geosociais gays
}

\author{
Technology georeference: Grindr and Scruff gays \\ geosocial networking
}

João Maia

Pós-doutor em Estudos Culturais pela UFRJ, doutor em Sociologia pela Université de Paris V (René Descartes). Atualmente é professor associado da Faculdade de Comunicação Social da Universidade do Estado do Rio de Janeiro, onde coordena o grupo de pesquisa CAC Comunicação, Arte e Cidade.

Eduardo Bianchi

Doutorando pelo Programa de Pós-Graduação em Comunicação da Universidade do Estado do Rio de Janeiro. Mestre em Comunicação pelo PPGCOM/UȨRJ. Atualmente é professor do Curso de Comunicação Social da UCAM. Membro do Grupo de Pesquisa Comunicação, Arte e

Cidade - CAC.

Resumo: Propomos investigar as redes geosociais de smartphones que utilizam a tecnologia de geolocalização. Como tais redes contribuem para o reconhecimento social e formação das múltiplas territorialidades da cidade. Veremos a configuração de mapas sensíveis tomados pelas emoçóes "afetuais" e, quando não, "desafetuais" do cotidiano. Nossa análise é a partir das redes geosociais Grindr e Scruff, direcionados aos diferentes grupos gays. Palavra-chave: Comunicação, Redes Geosociais, Gay.

Abstract: We intend to investigate geosocial networking applications used in smartphones that uses technology georeference. How these networks collaborate to social recognition and How They create multiple territorialities in the cities. We will see sensitive maps based on affective and disaffected que emotions users feel daily. Our analysis Relies in social apps such as Grindr and Scruff targeted to different gay groups. Keywords: Communication, Geosocial Networking, Gay. 


\section{Introdução e método de pesquisa}

Nossa pesquisa se orienta pela imersão em campo, on-line e off-line, no convívio com o objeto. A integração na pesquisa de campo não se origina na construção de perguntas objetivas, que irão ser comprovadas e testadas de maneira definitiva, mas vão se realizando paulatinamente e sem ter a pretensão de uma integração completa imediata. Observaremos os usos das redes geosociais Grindr e Scruff (aplicativos de redes sociais direcionadas ao publico gay).

Surge um problema metodológico singular em que as condiçôes de pesquisa se tornam uma "variável complexa", ou seja, as percepçôes e interpretaçóes do observador são expressivas, carregadas de simbologias históricas - memórias afetivas vividas ou intuídas. A questão se concentra na maneira de traduzir as estruturas encontradas (observadas) conjugando-as com os interesses teóricos.

Para fazer surgir os aspectos que estariam supostamente ocultos, "desbravando” o não dito, é necessário manter uma perspectiva teórica que coloque em evidência as estruturas de pertencimento do ator social e, ao mesmo tempo, perceber e problematizar suas interaçôes (GOFFMAN, 1984, MAFFESOLI, 1998). É necessário acentuar o fato de procurarmos apoio teórico, relaçóes de sentido que podem ajudar a explicar nosso conhecimento do mundo, mas sua origem está concentrada nas experiências que se desenrolam no cotidiano, na vida do homem comum que circula pelas ruas, antes da ciência. Assim, as informaçóes recolhidas, a partir de entrevistas abertas e conversas informais constituirão a base para compreender os elementos da "realidade cotidiana", um sistema livre de entrevista, sem amarras, buscando nas entrelinhas as subjetividades do não dito. Para Canevacci: "subjetividade é também (1) abstração, cujos níveis cognitivos são plasmados por razóes e emoçóes, reflexões e expressóes" (2004, p. 139).

Afirmamos a pretensão de trabalhar com um método que seja capaz de apresentar cientificamente a ação social, porém, preservando em sua base o significado que as açôes possuem para os seus atores.

Propomos pensar nosso objeto a partir da investigação sobre as novas concepçôes e inscriçôes espaciais que iremos irremediavelmente verificar nas formas das construçốes do cotidiano que estão se manifestando no presente da cidade.

É claro que não pretendemos visualizar a totalidade cultural em nosso recorte - Rio de Janeiro - dadas as zonas de opacidade, de sombras e de imagens plasmáticas oriundas das diversas telas da contemporaneidade.

Visualizamos o homem que se inscreve em meio aos grupos, tribos que compóem a cidade, transformando-a com seus desejos, sonhos e experiências. Interessa-nos, desta forma, trabalhar com o homem que participa da sociedade, exteriorizando suas crenças, no interior do mundo social, e que o interpreta como realidade. Assim, nosso interesse ficará demarcado, delimitado e nosso recorte de pesquisa estará mais bem definido.

A “organicidade presente no social” se formalizará a partir do pensamento 
de Georg Simmel sobre a noção de "sociabilidades". Este termo surge para ressaltar os materiais que preenchem a vida, a existência, os movimentos de grupos. Segundo o autor, as sociabilidades são fenômenos que têm vida própria. "São liberadas de todos os laços de conteúdos; existem por si mesmas e pelo fascínio que difundem pela própria liberação desses laços” (1983, p. 168).

As socializaçôes são, então, as formas pelas quais diferentes maneiras, graças as quais os indivíduos, em virtude de interesses - sensíveis ou ideais, momentâneos ou duráveis, conscientes ou inconscientes, casualmente agitados ou teologicamente estimulantes - se ligam em unidade no seio dos interesses aos quais se realizam enquanto membros. (SIMMEL, 1981 p.122). Ainda segundo Simmel, são os interesses e as necessidades que fazem os sujeitos se unirem em grupo, "em associaçóes econômicas, em irmandades de sangue, em sociedades religiosas, em quadrilhas de bandidos" (idem). Por que não em redes sociais on-line? Para Simmel, a forma lúdica da socialização constitui a sociabilidade. Este pensamento nos induz a desenvolver uma pesquisa empírica que demanda um olhar associado ao posicionamento de outras ciências que também valorizam a "proxemia", um sentimento de pertencer, fazer parte de um grupo de identificação, como afirma Maffesoli (1998), assim como a comunicação, para falar de um espaço contemporâneo.

Os pensamentos que valorizam os processos de coesão social, ou seja, os fatores de uniáo e de solidariedade dos grupos, induzem-nos a refletir sobre a "organicidade presente no social". A sociologia do conhecimento nos possibilita recolher de maneira mais orgânica os discursos que possuem sua origem na sociabilidade. A pesquisa e seu objeto são constituídos de elementos plurais e dinâmicos. O local que o homem ocupa não é construído segundo um modelo ideal e linear de desenvolvimento, mas tem sua constituição a partir de elementos heterogêneos e criativos.

Acreditamos na necessidade da utilização da pesquisa netnografica. A netnografia, o estudo de campo na Internet, uma nova forma de empirismo, é a representação de um trabalho de campo que tem como suporte a conexão para as interaçóes sociais no âmbito digital. O pesquisador muda a estrutura que o representa, sua presença está concentrada em um diferente meio de observação e participação.

Da mesma forma que a etnografia, o pesquisador que faz uso da netnografia necessita se entregar em sentidos. Em uma pesquisa que utiliza a netnografia como metodologia, há necessidade de uma maior sensibilidade do que é visto, o olhar do pesquisador deve estar muito mais aguçado. A velocidade das informaçôes exige uma atenção multiplicada, pois os contextos se perdem rapidamente em meio às rápidas trocas de mensagens, e tantos outros recursos comunicacionais empregados on-line. Nossa netnografia será feita a partir da demanda do objeto estudado, os suportes de comunicação moveis (smartphones), afinal, estará em nossas análises os usos dos aplicativos de redes geosociais que utilizam tecnologia de geolocalização (2). Teremos como base os aplicativos Grindr e Scruff, redes sociais direcionadas para o público gay. Utilizaremos essas plataformas como mediadoras para mantermos contato 
com seus usuários.

\section{Multiterritorialidades e as representaçóes compartilhadas}

Nossa investigação tem como ponto de partida as "representaçóes". Segundo Pesavento (2003), as representações são construções a partir do real, uma construção social e subjetiva, são portadoras do simbólico, carregam sentimentos e têm a capacidade de se ver como a própria realidade. Assim, buscaremos problematizar as representaçóes que se elaboram na rua, nos espaços públicos da cidade do Rio de Janeiro e como elas os (re)territorializam, por meio de açóes sensíveis dos diferentes grupos, transformando as territorialidades, por meio de disputas, negociaçóes ou ausência de embates, as culturas da cidade e suas territorializaçóes.

Junto à metodologia de análise dos usos desses aplicativos nos espaços da cidade, buscamos pensar as multiterritorialidades que compóem os espaços públicos, redesenhados cotidianamente e que ganham maior mobilidade com as apropriações das tecnologias móveis. Essas territorializaçóes dos espaços, em constante por vir, mutantes e mutáveis, híbridas pelos usos dos diferentes grupos que as apropriam e as ressignificam, interculturais pelas manifestaçóes criativas do dia-a-dia, comungam as ambiências e transformam os espíritos dos lugares. As relaçóes sociais que vão se estabelecendo pelos processos de territorialização emocional, tem no "afetual" as bases para nossos questionamentos de pesquisa.

Para Haesbaert (2010), as territorializaçóes se dariam com as relações de domínio e apropriação do espaço, ou seja, nossas mediaçóes espaciais do poder, poder em sentido amplo, que se estende do mais concreto ao mais simbólico. Apropriaçóes que se dão pelos usos das materialidades e, por conseguinte, atribuindo-lhes novas subjetividades que são compartilhadas de forma cotidiana, por assim dizer, concedendo-lhes sentimentos a partir de emoçôes vividas.

No dia 11 de janeiro de 2013, o Jornal The New York Times elegeu as 46 cidades para se visitar em 2013 (3) e a Cidade Maravilhosa está no topo da lista. Mas de onde vem esse reconhecimento? Por que a cidade do Rio de Janeiro retoma seu destaque no cenário nacional e internacional? Faz tempo que não é a capital federal, continua não sendo o centro econômico do país, apesar de demonstrar seu crescimento. Sim, é verdade, o Rio de Janeiro foi sede de jogos da Copa das Confederaçóes e da Jornada Mundial da Juventude, ambos eventos de 2013, (esse ultimo ligado à igreja católica), será palco da final da próxima Copa do Mundo de Futebol (2014), e é a próxima cidade olímpica, que receberá, em 2016, atletas de todos os cantos do mundo.

Esses são os eventos destacados pela matéria do The New York Times, para dar aval, ratificar e legitimar suas escolhas. Contudo, percebe-se uma superficialidade no que tange as representaçôes e, por assim dizer, o imaginário que se funda à cidade do Rio de Janeiro. Os eventos deslumbram a cidade, a recolocam em cena, mas para ser escolhida como sede das festividades precisou-se destacar suas qualidades. Foram destaques: a rua e seu povo.

A proposta desse trabalho é pensar a cidade e suas múltiplas identidades, 
mas para além disso, refletir os fragmentos culturais de nosso tempo. Propomosnos pensar a cidade por seus espaços ressignificados, ou seja, buscamos, nas atribuiçôes simbólicas, as territorialidades que refletem a emoção, a sensibilidade do estar-junto. Assim, decidimos por um recorte especifico para o estudo que estamos apresentando. A partir de agora, veremos a emergência de alguns dos fragmentos das culturas que compóem a cidade do Rio de Janeiro, as culturas das territorialidades gays, amplificadas pelo uso da tecnologia de geolocalização que estão apropriadas pelas redes sócias de aplicativos de smartphones - redes geosociais. Que a caçada comesse.

\section{Geolocalizaçáo e a mudança nos espaços sensíveis da cidade}

A cidade do Rio de Janeiro foi eleita em 2009, segundo a $10^{\text {a }}$ Conferência Internacional de Turismo LGBT, o melhor destino gay do mundo. Em 2010 e 2011 foi eleita como o destino gay mais sexy do mundo. "A eleição foi realizada pelo site TripOutGayTravel.com, em parceria com a MTV americana". Uma cidade gay que se destaca pela cultura urbana, a cultura dos espaços públicos, das praias, dos bares, das festas e das vivências nas ruas.

Acreditamos em uma cultura da rua que se quer lenta e relacional, mas que se apropria da tecnologia para dinamizar o prazer e o gozo. Os suportes, smartphones, que, munidos de aplicativos específicos (baixados nas lojas on-line, específicas para cada sistema operacional), precipita as conversas e potencializa a possibilidade da prática sexual.

Discutiremos os modos de utilizaçáo dos instrumentos de comunicação a partir dos usos da Internet, com seus aplicativos. As redes geosociais de aplicativos de telefones smartphones como Grindr, Scruff, apropriados e ressignificados emocionalmente pelos usuários dessas tecnologias. O lúdico e o onírico são depositados nesse tipo de suporte comunicacional, mediador, também, da vida social. Percebendo, portanto, esses dispositivos móveis como elementos de "coesão social", respaldado pelos desejos, pelas vontades e todos os tipos de quimera que se deposita em uma "caçada sexual".

A "caçada", através dos usos dos aplicativos, tem, também, seu valor lúdico. A disposição do usuário não está, necessariamente, no encontro fora da rede social. O jogo de seduzir e ser seduzido, de desejar e ser desejado excita ainda mais a performance das trocas de mensagens, imagens e vídeos. O lúdico está no tempo depositado na experiência sensível da comunicação mediada pelos aplicativos. O usuário sexualiza a performance cria suas imagens, e goza no prazer do desejo do outro. Náo estamos falando, necessariamente, de um gozo físico, mas de um gozar a vida, de um prazer inebriante de horas de excitação com vários outros membros excitados - em todos os sentidos do termo.

Os aplicativos, aqui estudados, são meios rápidos, simples, gratuitos (em sua maioria) para encontrar e conhecer pessoas gays, bissexuais e curiosas, para amizade e/ou encontros sexuais. Os usos e aplicabilidades são diferentes de usurário para usuário e de tempos em tempos.

Grindr e Scruff são aplicativos para smartphones, podem ser usados nas seguintes plataformas: iPhone, iPod touch, iPad, Blackberry OS, e no sistema 
operacional Android. Os downloads são feitos em lojas virtuais, tendo cada sistema operacional sua própria loja. Esses são aplicativos que utilizam GPS (sistema de posicionamento global), ou seja, eles localizam pessoas que usam o mesmo aplicativo. O Scruff apresenta um sistema que possibilita conversar com pessoas de todo o mundo, ampliando as possibilidades das relaçóes sociais. Pode ainda fazer simulaçôes de localização. Por exemplo, o usuário substitui a cidade de origem, por uma que gostaria de estar, ele pode conversar com outros usuários dessa mesma cidade. Outro exemplo, bem mais objetivo, é a possibilidade de substituir a cidade de origem por uma de destino, como a de uma viagem nesse caso, o usuário já pode conhecer perfis de outros usuários, trocar mensagens, fotos, vídeos e marcar seus futuros encontros. Todos a bordo, sexo garantido.

Através de uma interface simples que exibe uma grade de imagens representativas dos usuários, os perfis ficam dispostos a partir do mais próximo ao mais distante. $\mathrm{O}$ primeiro perfil apresentado na tela do smartphone é do proprietário do aparelho, já os perfis que se seguem são dos usuários que estão mais próximos, em menor distância. Ao selecionar a imagem de um dos membros da rede social, um breve perfil do usuário será maximizado - idade, altura e distância que se encontra do observador interessado, além de observaçôes particulares descritas pelo usuário em questão, ou nada disso, fica a critério do dono do perfil as informaçóes que constarão (6). Na tela do aparelho constará ainda a opçáo de bate-papo, representada por um baláo azul (típico dos diálogos de histórias em quadrinhos), uma estrela que é a possibilidade de "favoritar" o usuário que está sendo observado, uma bandeira lilás que quando escolhidas tem a função de denunciar o usuário por infração cometida (previamente estabelecida pelo contrato de uso da rede social) e um "xis" vermelho, ícone para bloquear o perfil do usuário, essa escolha impede que os usuários se vejam on-line na rede social.

Retirando os possíveis pesos deterministas que possam recair sobre os usos das tecnologias móveis, percebe-se uma relação de prótese dessas mídias nas práticas do cotidiano, que vão para além da "extensão do homem" (McLUHAN, 2011). Os suportes tecnológicos, que possibilitam o ator social amplificar seu deslocamento e permanecer em comunicação, são incorporados às necessidades da vida contemporânea. Ficamos entorpecidos, como diria McLuhan, com nossos gadgtes, perdemos parte de nosso tempo debruçados sobre eles, melhor dizendo, ganhamos tempo pelas experiências que esses suportes mediam, tempo de experiência é investimento social. Ganhamos novas formas para estabelecermos nossos laços sociais e, diferentemente de Narciso, não morremos em nós mesmos. Investimos no outro e com o outro nossas vidas. Essas tecnologias nos possibilitam amplificar o que já vínhamos fazendo: comunicação.

O impacto que os usos dessas tecnologias provocam no dia-a-dia, como ferramentas que auxiliam as relaçôes socioespaciais, são percebidas facilmente pela reconfiguração das experiências que transformam os ambientes. Apropriando-se das mídias móveis, pela vazão criativa dos usos, os sujeitos 
redesenham os espaços urbanos, reconstruindo as territorialidades que marcam a cidade. A tecnologia móvel contribui para a reinvençáo dos caminhos que fazemos da cidade cotidianamente. Marcamos e desmarcamos nossos traçados, nossas trilhas são refeitas pelos nossos modos de ser, ou melhor, de estar no mundo.

Frisamos que nossa proposta está no uso desses suportes de comunicação, como elementos agregadores, "objetivando" vínculos afetivos como: amizade, encontros e sexo. Além dessa união causada pela circulação da informação, assumimos que o uso das tecnologias de informação e comunicação (TICs) servem como base para um novo modo de inscrição dos atores sociais no sistema de produção da cultura e das reaçóes de socialidade.

Vislumbram-se as manifestações das culturas no cotidiano, a ações conjuntas dos atores sociais como fonte de suas identificaçóes e, portanto, formação dos grupos emocionais. Percebemos o cotidiano como a valorização do local e privilegiando o "aqui e agora" das interaçôes, por conseguinte, a formação de laços sociais moles, moventes, mas não menos intensos.

Michel Maffesoli acredita que vivemos um momento de "mistério das conjunçóes" (2009), onde encontramos uma fragmentação, os sujeitos se agrupam, se reconhecem pelas necessidades, pelos desejos comuns. Para o autor vivemos uma "ética da estética", um "estar junto" que valoriza o prazer de querer viver, base para as expressóes das emoçóes coletivas.

Ainda segundo Maffesoli, estamos em um momento para pensar o "ideal comunitário" (2012), em que o individuo se dilata, onde o "eu" é percebido como "nós". As experiências comunitárias se dão em troca, pelo compartilhamento das sensaçôes, dos desejos carregados de simbólico. Percebe-se o desejo na organicidade da vida, na vontade de reconhecimento e troca de emoçóes. $\mathrm{O}$ autor em entrevista diz que (8):

Graças à web, às redes comunitárias, aos fóruns de discussão e outros blogs, acessamos não mais "um outro mundo", mas sim "um mundo outro". Isto é, um mundo que faz parte das dimensóes que o racionalismo moderno deixara de lado. Falo de tudo o que diz respeito à dimensão lúdica, onírica, imaginária da existência. É essa ligação entre o "arcaísmo" e o desenvolvimento tecnológico que me leva a não compartilhar o pessimismo que se dissemina entre as elites sociais. Existe hoje, em particular entre as jovens geraçóes, uma inegável vitalidade, que se exprime em novas formas de solidariedade e de generosidade. A web favorece antigas formas de hospitalidade, que foram a marca das sociedades pré-modernas (2012) .

Assim, esta pesquisa volta-se à problemática, análise e reflexão sobre as diversas formas de socialidade que servem para afirmar o papel da cultura que se elabora a partir dos movimentos comunicacionais do dia-a-dia.

Nossas problemáticas são levantadas a partir da análise das relaçóes sociais estabelecidas pelo homem em seus "lugares" de vivência. Tais vivências são observadas a partir das experiências sensíveis, boas ou ruins. Portanto, afeto e desafeto ajudam a pensar os espaços da cidade como ambiências do vivido, reconfigurados pelas práticas sociais do cotidiano. 
As diversas socialidades, tendo como base a cultura, sáo pontos de observação da presente pesquisa. Através de categorias tais como: "cotidiano", "grupo/tribo", "velocidade e lentidão" e "rede", poderemos apreciar os homens transformando e negociando de diversas formas a construçáo do sentido local. Através dos usos dos espaços da cidade, territoralizandos pelos sentimentos de pertencimento, percebemos as ambiências afetuais sendo compartilhadas pelos grupos que se apropriam dos espaços sensíveis, locais de afeição comungadas pelas relaçóes emocionais estabelecidas pelo convívio cotidiano.

As discussões do café do comércio, as banalidades da vizinhança, as tiradas e as saudaçóes que pontuam os trajetos cotidianos, sem esquecer o corpus de sentenças e de provérbios que servem a toadas as ocasióes da vida, tudo isso não se baseia na obsessão pela verdade, adequatio rei ad intellectum, nem funciona pela busca tetânica de um processo dialético, mas, ao contrário, apresenta uma bonomia que sabe que diante da derelição da finitude há coisa melhor a fazer do que apostar a vida em ideias, seja qual for a solidez conceitual. (2009, p. 50)

As histórias cotidianas, histórias contadas pelo homem comum, ajudam à clarificar o papel socio-cultural na cidade em que vive, e, por conseguinte, no panorama cultural gay do Rio de Janeiro, parte fundamental de nossa análise. Percebemos, ainda, como o conceito de "grupo/tribo", pode ser encarado como a estrutura para a reflexão acerca das organizaçóes culturais construídas em "redes". Pensamos os jogos de tensão que se estabelecem na luta pelo poder simbólico e de representação da cidade junto aos contínuos processos das (re)territorializaçôes dos espaços públicos. Vemos as negociações e roçaduras como parte intrínseca ao "ideal comunitário" (MAFFESOLI, 2012), necessários para os reconhecimentos limítrofes de poder sobre o espaço. Observamos os movimentos entre a "velocidade e lentidão" dos fluxos informacionais circunscritos na rua, nos encaminhando a refletir sobre os movimentos comunicacionais que evocam a constituição da sociabilidade comunitária.

\section{Territorialidades temporárias e a as novas formas de experiência}

Diante da fragmentação cultural e da efervescência dos processos informacionais surge um novo tipo de sociabilidade que se estabelece entre os indivíduos na cidade contemporânea. As relaçóes entre os homens nos induzem a pensar sobre os fluxos comunicacionais que ora evocam a fluidez e a celeridade, mas em outros momentos sugerem enraizamentos, uma fixidez, uma (re)territorialização do espaço urbano que é compartilhado, negociado e ressignificado junto ao dinamismo contemporâneo.

As ideias, os produtos da cultura e os costumes do homem comum, do homem que vive em meio à rua junto aos outros sujeitos, criando laços, afetos, e ambiências, agregam valores à constituição cultural da sociedade como um todo. A cidade contemporânea se agiliza e se mostra como um campo fértil para a velocidade da informaçáo. Contudo, mesmo nessa cidade de dinamismo comunicacional, percebemos um processo de resistência nas açóes do homem comum. Há a valorizaçáo do momento lento, o momento da comunhão, suas relaçóes afetivas compartilhadas no aqui e agora constituidoras das culturas das ruas, dos bares e das praias com seus tempos desacelerados do lazer, do 
descanso e do gozar à vida.

Os movimentos comunicacionais e os fluxos informacionais, que circulam na cidade, são, também, negociados pelos atores sociais que comungam interesses e desejos comuns, reivindicam maneiras de pensar o mundo a partir de seus estilos de vida. Segundo Giddens, estilo de vida é "um conjunto mais ou menos integrado de práticas que um indivíduo abraça, não só porque essas práticas preenchem necessidades utilitárias, mas porque dão forma material a uma narrativa particular da auto-identidade" (2002, p.79).

Pensamos para além das "formas materiais" que Giddens descreve. Essas materialidades, que delimitam as práticas do cotidiano, ganham novos usos, novos valores simbólicos, pois são impregnados de sentido, de valores emocionais, fazendo-se assim, pela sensibilidade. Os atores se apropriam do espaço público demarcando-o como posse, uma territorialidade simbólica, uma imaterialização sensível dos espaços da cidade. Pensamos essa "auto-identidade" em constante reformulação, baseada por sociabilidades, pelas trocas de informação que circulam pela cidade comunicacional. Acreditamos em uma relação de identificação, que reconfigura as transformaçóes pelas quais os sujeitos contemporâneos passam.

Os homens contemporâneos, comunicacionais, carregam, junto com seus modos de ser e estar no mundo, informaçóes produtoras de sentido, que pautadas por significaçóes ambientam a cidade. Constrói-se, com as experiências que ambientam os diferentes meios sociais, territorialidades, que quando pensadas junto aos suportes de comunicação móveis se fazem temporárias não frívolas, mas ágeis, transitórias que fazem parte das novas formas de se fazer história.

Percebemos temporalidades distintas nas localidades que se deslocam. "Com a atual fase dos computadores ubíquos, portáteis e móveis, estamos em meio a uma 'mobilidade ampliada', que potencializa as dimensôes física e informacional" (LEMOS, 2011, p. 17). A mobilidade dos espaços que se movem, por meio de suportes de comunicação móvel, propiciam novas formas de experiências na cidade.

Essas mídias movediças, virtualizadas (mas que não perdem seu caráter físico e presencial), possibilitam múltiplas conexôes e fazem parte do cotidiano de forma irrestrita. A tecnologia da velocidade também apresenta seu tempo de lentidão. Os locais de seus usos (espaços ambientados) determinam a velocidade das apropriações e ressignificações das práticas sociais on-line.

A praia com sua lentidão do lazer, descanso, lugar de namorar, relaxar ouvindo música e das práticas de esportes náuticos ou de areia, é também espaços de digitalização da vida. Nos momentos de descanso e descontração, uma imagem pode ser captada e fazer parte do perfil de uma rede social on-line, mensagens podem ser trocadas com amigos, encontros podem ser marcados. Isto é a vida "virtualizada", experiências do cotidiano que se transfigura em informação, em troca e em socialidade.

Os frequentadores dos bares, das praias, os que vão para beber com os 
amigos e os que vão para namorar, imprimem distintos ritmos ao processo acelerado da cidade. Os produtos das culturas servem como suporte para pensar as relaçóes sociais que se estabelecem vagarosamente de maneira localizada e próxima. Contudo, com as tecnologias de informação e comunicação móveis, os localismos se refazem pelos caminhos que se transfiguram pelo movimento das mídias locativas.

Os fluxos presentes no ritmo acelerado das informaçôes, nas múltiplas conexóes que se estabelecem via smartphones, conectados à Internet, interligados em mensagens instantâneas, penetram os espaços da rua e, assim, transformam as experiências dos sentidos, refazem a cultura local. Os usos de redes "geosociais" funcionam como agentes que agregam, são facilitadores das interaçôes sociais.

Vamos discutir como são criados alguns valores característicos da cultura contemporânea, vistos como vetores de agregação, coesão e estabelecidos cotidianamente, a partir do uso material da cultura tecnológica.

\section{As redes e as práticas: "pegaçáo” conectada}

Veremos agora, a partir de exemplos de nossa pesquisa empírica, as relaçôes de homens, suas relaçóes sociais (re)configurando os espaços públicos e como o domínio da técnica pode ser apropriado pela busca do prazer.

Recuero (2010) nos ajuda a estudar as redes sociais da Internet como forma de problematizarmos as relaçóes sociais de laços multiplexos, no qual os sujeitos apresentam interação em diferentes espaços e sistemas, ou seja, on e off-line. Nos levando, portanto, a perceber os usos dos aplicativos das "redes geosociais" como mediadores sociais, suportes midiáticos empregados subjetivamente para diferentes formas de interação.

A investigação parte das histórias contadas, tendo a cidade como palco e as experiências atreladas aos suportes de mídias móveis. O que salta aos olhos é a exuberância da rua com seus frequentadores, a sociabilidade que se configura e a cultura que se apresenta. O que leva os usuários das redes sociais de geolocalizaçáo voltadas para encontros saírem de suas casas a qualquer hora do dia para práticas sexuais? Mero gozo? Acreditamos na valorização da experiência sensível com o outro, na formação de laços afetivos.

Questionamos como esses atores sociais buscam nas "brechas" do dia-a-dia formas de esquivar das "estratégias" "impostas", como afirma De Certeau (1994), e, assim, como buscam na porosidade do cotidiano manipular o velho e transformá-lo em algo novo, que esteja dentro do imaginário dos grupos que os atores se inserem. Como o cotidiano é transformado por eles, através da criatividade nas artimanhas que os impulsionam à posição de consumidores e produtores da cultura urbana carioca. Estamos nos remetendo às múltiplas formas de se comunicar, de se colocar para o mundo. São as infinitas formas de narrativas que nos guiam a perceber os usos dos corpos, dos andares, dos mapas (caminhos e desvios), das palavras escolhidas, de como elas são ditas e por quais meios elas são usadas. A tecnologia auxilia na configuração desse homem e suas relaçóes com os outros, na amizade, na simplicidade do ato sexual 
casual e nas relaçóes perduram.

Buscamos, no cotidiano, um estar junto (MAFFESOLI, 2010), compartilhando e configurando a rua, a cidade. Esses grupos, com seus diferentes tipos, se posicionam e se impóem. Fincam suas bandeiras coloridas pela praia de Ipanema e andam com elas estampadas em suas roupas. Demarcam suas territorialidades em meio ao vivido, na imaterialidade das experiências, suas áreas de influência e reivindicam seu poder local. É essa cultura que se transforma e se fragmenta, que desliza nos seus significados e que está em constante transformação. Esse é o produzir cultural, que ressignifica o cotidiano através da cultura comunicacional. Corpo, beleza, tecnologias são questóes que nos ajudam a entender as relaçóes sociais que se dão nos espaços da cidade, influenciados pelas tecnologias móveis.

O corpo nu ou adornado é um importante meio de comunicação quando pretendemos estudar esses aplicativos. É o corpo, disposto nos perfis das redes sociais, que chama a atenção no primeiro olhar. Os aplicativos têm por norma de uso punir com exclusão do perfil o usuário que colocar imagens de corpos nus. Mas, para burlar esse impedimento, muitos são os membros fálicos eretos sob as cuecas, toalhas de banho e lençóis. São as táticas, as "artes de fazer” com as possibilidades, tomadas pelas astúcias que possibilitam trapacear as estratégias, as normas e diretrizes verticalizadas (De CERTEAU, 1994). Os sujeitos recriam sobre as regras e impóem suas vontades através de apropriaçóes criativas.

Aqui, a "ética da estética" é a aparência dos peitos expostos, dos volumes entre as pernas, dos rostos e de muitos corpos sem suas respectivas cabeças. Nem todos mostram o rosto e são muitos os corpos sem rosto. Surge, assim, o desejo de descobrir o que está inebriado, escondido, velado pelas diferentes convençôes sociais - familiar, cultural, social, sexual. Muitos homens casados, noivos ou namorando em relaçôes heterossexuais, tem seus perfis nessas redes, muitos buscam sexo com "discrição" (9).

São diversas as formas de apropriação e utilização dos instrumentos de comunicação móveis, smartphones, e suas variações de uso, pelos quase infindáveis aplicativos, que buscam agradar aos mais diferentes e excêntricos gostos e necessidades. Estando esses suportes de comunicação conectados à Internet, mostram muitas das potencialidades desses instrumentos de comunicação e informação. Dentre essas tantas possibilidades, estão as redes geosociais. Entendemos o conjunto smartphone e redes gesociais como mediadoras de “coesão e auto-afirmação social", produtoras de sentido e reconhecimento pelo “estar junto", que se deslocam pela cidade, traçando rotas, desenhando mapas, (re)criando caminhos de sentimentos. As mídias que se locomovem pela cidade com ajuda dos corpos, reconstroem simbolicamente a cidade pelo reconhecimento dos espaços que se reconfiguram em lugares experienciados, lugares de trocas de experiência, lugares de um ludismo de prazer.

Locais de passagem, como aeroportos e rodoviárias, se refazem pela sensibilidade. Não há monotonia nas salas de espera, entre um embarque e outro, as mensagens são trocadas e os primeiros encontros podem ocorrer ali mesmo, 
ou nos reservados dos banheiros. Rafael (10) conta como teve uma experiência no Aeroporto Internacional Galeáo, Rio de Janeiro. Um atraso de duas horas de espera poderia ser tedioso, mas não foi o que ocorreu. Rafael narra sua experiência pela necessidade de relaxar. Morador do Rio de Janeiro, conta que estava irritado por não ter informaçóes sobre seu voo para Buenos Aires. A viagem a passeio que estava fazendo com amigos aparentava ficar comprometida: os amigos haviam embarcado por outra companhia aérea e Rafael teria que esperar solitário seu voo. Solitário? Rafael havia passado pelo Free Shop e se rendido às tentaçôes aromáticas vindas da França, aos chocolates suíços e as camisas do "jacaré" made in Bolívia, enquanto aguardava no saguão a chamada para embarque. Contudo, nem todo o prazer de ir às compras, prazer declarado com gosto por Rafael, aplacou a angústia da tediosa espera no grande e frio saguão do Galeão. Irritado, decidiu compartilhar sua insatisfação com seus amigos do Facebook e enquanto digitava, escutou o barulho de mensagem do aplicativo Scruff. Rafael havia chamado a atenção de alguém. Rafa, apelido que está em seu perfil de usuário, decidiu investir seu tempo trocando algumas mensagens e algumas fotografias, ele e o novo amigo decidiram se encontrar, sim, a outra pessoa estava no mesmo saguão. Conversaram pessoalmente e o papo esquentou os desejos, que não foram possíveis de serem controlados. "Convidei ele pra ir no banheiro e ele aceitou [...] fiquei com medo de ser roubado, sei lá... tem tanto maluco por aí, e vamo combinar, ladrão náo tem cara... e que cara, ele era um tesão." Rafael é bastante detalhista, e aparentava gostar de contar com detalhes a experiência. Disse que foi ótimo, mas achou uma pena "nem eu nem ele tinham camisinha", e fez cara de triste, mas completa: "Só não rolou penetração, mas de resto... foi Ótemo" (11). O entrevistado contou que nunca mais teve contato com o "cara do banheiro": "Foi só pra aliviar", frisa Rafael.

As tecnologias móveis possibilitam conectar-se com alguém que está em uma rodovia, passando a poucos quilômetros dentro de um ônibus e descobrir um novo romance. Em uma entrevista, José contou que estava em uma viagem para descansar. Em determinada hora de sua viagem, decidiu ficar on-line em seu perfil do aplicativo Grindr e começou a conversar com outro usuário, que estava voltando para a mesma cidade de José, Rio de Janeiro. A conversa fluiu bem, dias depois marcaram um encontro, houve reconhecimento pelos gostos, o sexo foi bom e, pouco depois começaram a namorar. "Esse brinquedinho (13) é ótimo [...] funciona super bem".

Eram quase onze horas da noite de uma terça feira. Felipe (14) tinha acabado de fazer sua série na academia de ginástica e foi para o banheiro tomar um banho. Apenas ele e um outro homem estavam no vestiário. Felipe conta que fez um breve cumprimento com a cabeça, e disse um "Oi”, que quase não se pode ouvir. Conta que foi fortemente encarado pelo outro sujeito e que retribuiu. Tirou a roupa, pegou a toalha na mochila e entrou no box para tomar um banho e tirar o suor. $O$ banheiro da academia tem seus reservados para banho dispostos lado a lado e todos com uma porta. O outro homem ligou o chuveiro ao lado, jogou a toalha sobre a porta. Felipe conta que em segundos eles estavam compartilhando a mesma ducha. Os corpos se roçaram e houve uma explosão orgástica. "Depois de terminar fui pra casa [...] Dois dias depois 
liguei o meu Grindr, conversei com um carinha que mora perto de mim... já tinha falado algumas vezes, mas nunca rolou nada. [...] Mas dessa vez decidimos que íamos nos encontrar. Foi minha surpresa quando trocamos fotos [...] já tinha trocado foto de pau e bunda, mas nunca de rosto... era ele, era o cara do banheiro da academia... Foi muito engraçado". Depois dessa conversa, ele e Bruno (nome do homem da academia) ficaram amigos e nunca mais tiveram relaçóes sexuais. "Perdi uma foda, mas ganhei um amigo... Tá valendo".

As tecnologias móveis estão ajudando a redesenhar os espaços da cidade. Os atores sociais reocupam a cidade pelos mapeamentos que traçam pelos desejos dos encontros. Percebemos os usos desses aplicativos pela cidade de forma indistinta: shoppings, praças e praias, nos ônibus e nos bares. São muitos os casos em que vemos homens nos cantos das boates fazendo suas caçadas, que podem terminar pelas pistas de dança, nos banheiros das boates, nos quartos dos motéis ou nos das próprias casas. Em dias menos felizes, podem acabar em nada, afinal, nem todo dia é dia do caçador, neste caso, nem da caça.

As redes de "pegação" podem ter diferentes apropriaçóes e isso vai depender dos usos e das necessidades dos momentos de cada usuário. As relaçóes podem ser mais frívolas, no sentido de passageiras e não, necessariamente, fúteis. Talvez sejam mais superficiais no que tange as emoçôes mais românticas, mas não menos intensas. Rafael é nitidamente intenso em suas emoções. Vemos tal intensidade através do entusiasmo em que conta suas experiências. Rafa tem intensidade ao se jogar para a vida. 


\section{Referências Bibliográficas}

CANEVACCI, Massimo. Cidades Polifônicas: Ensaio sobre a antropologia da comunicação urbana. São Paulo: Studio Nobel, 2004.

De CERTEAU, Michel: A invenção do cotidiano: Artes de fazer. Petrópolis: Editora Vozes, 1994.

GOFFMAN, Erving. Lês rites d'interaction. Paris, Minuit, 1984.

HAESBAERT, Rogério. O mito da desterritorialização: do "fim dos territórios" à multiterritorialidade. Rio de Janeiro: Bertrand Brasil, 2010.

LEMOS, André. Mobilidade e espaço urbano. (In): BEIGUELMAN, Giselle; La FERLA, Jorge. Nomadismos tecnológicos. São Paulo: editora Senac São Paulo, 2011.

McLUHAN. Marshall. Os meios de comunicação como extensôes do homem. São Paulo: Editora Cutrix, 2011.

MAFFESOLI, Michel. Homo Eroticus: Des Communions émotionnelles. CRS editions: Paris, 2012.

. O Mistério da Conjunção: ensaios sobre comunicação, corpo e socialidade. Porto Alegre: Sulina, 2009.

O tempo das tribos: o declínio do individu-

alismo nas sociedades de massa. Rio de Janeiro: Forense Universitária, 1998.

RECUERO, Raquel. Redes sociais na Internet. Porto Alegre: Sulina, 2010.

SIMMEL, Georg. Sociologie et épistemologie. Paris: P.U.F., 1981. . Sociologia. São Paulo: Ática, 1983.

\section{Notas}

(1) Grifo no original.

(2)Tecnologia que localiza o usuário a partir do seu IP (Internet Protocol - uma identidade que cada equipamento eletrônico possui) usando, por exemplo, o sistema GPS (Sistema de Posicionamento Global). O satélite localiza o gadget a partir deste número sabendo, assim, sua localizaçấo na Terra.

(3) http://www.nytimes.com/interactive/2013/01/10/travel/2013-places-to-go. html?_r $=0$

(4) http://www.revistaturismoenegocios.com/materia.php?c=304

(5) As açôes aqui descritas são baseadas no aplicativo Grindr, são parecidas com o 
Scruff, mas apresentam distintas possibilidades. As disposiçóes dos ícones e das informaçôes são diferentes. Alguns recursos são particulares dos aplicativos, mas destaco que o mais importante para essa pesquisa não está propriamente nos recursos dispostos, mas nos seus usos, nas apropriaçóes desses elementos comunicativos perante o desejo de socialidade.

(6) As informaçôes descritas são estruturadas pela rede social, mas cabe ao usuário determinar o que irá aparecer em seu perfil.

(7) Chamamos de "favoritar" a ação de marcar um outro usuário como contato preferencial. Assim, esse "amigo" poderá ser facilmente encontrado, pois fará parte de um espaço reservado.

(8) http://www.ihu.unisinos.br/noticias/514073-a-espiral-de-maffesoli

(9) Discrição é a palavra amplamente usada nesses casos específicos.

(10) Rafael, 27 anos, estudante, morador do bairro de Copacabana, Zona Sul da cidade do Rio de Janeiro (entrevista concedida em 27 de março de 2013).

(11) "Ótemo" está grifado, pois quisemos colocar um pouco de oralidade na transcrição. Nesse momento da conversa, o entrevistado enfatizou a palavra ótima.

(12) José, 42 anos, professor na cidade do Rio de Janeiro (entrevista concedida em 15 de janeiro de 2013)

(13) Brinquedinho é como José chama a rede social Grindr.

(14) Felipe é professor particular de inglês, morador do bairro de Vila Isabel, Zona Norte da Cidade do Rio de Janeiro (entrevista concedida em 23 de fevereiro de 2013).

(15) Expressão usada por muitos gays que quer dizer busca de encontros. 